\title{
In vitro antimicrobial screening of metal complexes of Schiff base derived from streptomycin and amoxicillin: Synthesis, characterization and molecular modeling
}

\author{
Narendra Kumar Chaudhary, Parashuram Mishra* \\ Bio-inorganic and Materials Chemistry Research Laboratory, M. M. A. M. Campus (Tribhuvan University), Biratnagar, Nepal \\ Email address: \\ prmmishra@rediffmail.com (P. Mishra)
}

To cite this article:

Narendra Kumar Chaudhary, Parashuram Mishra. In Vitro Antimicrobial Screening of Metal Complexes of Schiff Base derived from Streptomycin and Amoxicillin: Synthesis, Characterization and Molecular Modelling. American Journal of Applied Chemistry. Vol. 2 , No. 1, 2014, pp. 19-26. doi: 10.11648/j.ajac.20140201.15

\begin{abstract}
A series of three new metal (II) complexes of Schiff base were synthesized from the novel ligand derived from Streptomycin and Amoxicillin in stoichiometric ratio. They were characterized by elemental analysis and spectral techniques like IR, ${ }^{1} \mathrm{H}$ NMR, electronic spectrum and mass spectrum. IR spectral data suggested that the tetradentate ligand has coordination to metal ions through azomethine nitrogen, glycosidic oxygen and two amine nitrogens. Electronic spectral measurement indicated square planar geometry of $\mathrm{Ni}$ and $\mathrm{Zn}$-complexes and tetrahedral geometry of Cu-complex with diamagnetic behavior. Molar conductivity measurements revealed non-electrolyte nature of the complexes where metal ions have coordination through doubly negative charged anions of the Schiff base. The thermal behavior (TGA/DTA) of the complexes was studied and kinetic parameters were determined by Coats-Redfern method. XRPD technique revealed monoclinic crystal systems for $\mathrm{Ni}$ - and $\mathrm{Zn}$-complexes and hexagonal crystal system for $\mathrm{Cu}$-complex. The possible geometries of the metal complexes with their bond length were optimized by MM2 calculations using CsChem3D Ultra-11 program package software. Antibacterial sensitivity of the ligand and its metal complexes were assayed in vitro against four bacterial pathogens viz. E. coli, B. subtilis, S. aureus and K. pneumonia by Kirby Bauer paper disc diffusion method and showed moderate to better potency.
\end{abstract}

Keywords: Antibiotics, Aminoglycoside, Streptomycin, Schiff Base, $\beta$-Lactam

\section{Introduction}

The unbelievable adaptability and flexible metabolic power developed by disease causing pathogens are the major problems for the increased antibacterial resistance that requires myopic thinking in the scientific world and in the pharmaceutical industry. In the long journey of antibiotics, dating back from the discovery of naturally procured penicillin to the semi synthetic drugs [1], there is still a challenging and evolutionary demand in the field of medical science for the better search of efficacious therapeutic drugs. Mono therapy and multidrug therapy being unsuccessful [2], extensive research investigations have to be forecasted for the redesign of previous drugs, hoping desirous and improved activities against diseases. The drugs in conjugation with metal ions, after the discovery of cisplatin [3] has knocked coordination chemistry to be a subject of great interest and has now become a multidisciplinary area having a wide range of applications based on structural variety. Schiff bases are versatile pharmacophore [4] that cave in metal ions within it due to presence of various donor atoms and are considered to have medicinal and pharmaceutical importance with broad spectrum of biological significances like anti-tubercular [5], anticancer [6], antimicrobial, analgesic [7] and anti-inflammatory [8] actions. In search of new and potentially active Schiff base, we have selected two antibiotics viz. streptomycin and amoxicillin as a better starting compound and augmentation of antibacterial activity was reported by insertion of metal ions into synthesized Schiff base. Streptomycin (Str) is a bacteriocidal aminoglycosidic antibiotic with three components: streptidine, streptose, and N-methyl-Lglucosamine [9]. It was a first antibiotic actively used in the treatment of tuberculosis and also bears potential actions against non-tuberculosis infections caused by various bacterial pathogens [10]. Its antibacterial function is related 
to interference with normal protein synthesis. However, ototoxicity was the severe limitations of its use in clinical practice that causes permanent sensorineural hearing loss in human [11, 12]. Amoxicillin (Amx) is a semi synthetic bacteriolytic $\beta$-lactam antibiotic drug of class penicillin comparable to ampicillin in antibacterial spectrum and particularly used in the treatment of respiratory tract infections [13]. The bio-functional activity of amoxicillin is related to lactam ring that inhibits bacterial growth by proteolysis mechanism. In order to address their therapeutic failures and serious limitations, their modular design in derived form has spurred the growth of interest and been considered as a topic of research. In the present investigation, synthesis and characterization of novel Schiff base ligand (StrAmx) by using streptomycin and amoxicillin, and its transition metal complexes with different bio-metal ions due to their chelating behavior, have been reported. In vitro antibacterial evaluation of the novel ligand and its metal complexes was carried against $E$. coli, B. Subtilis, S. aureus and Klebsiela pneumoniea by measuring diameter of zone of inhibition in $\mathrm{mm}$ to know the potentiality of such compounds.

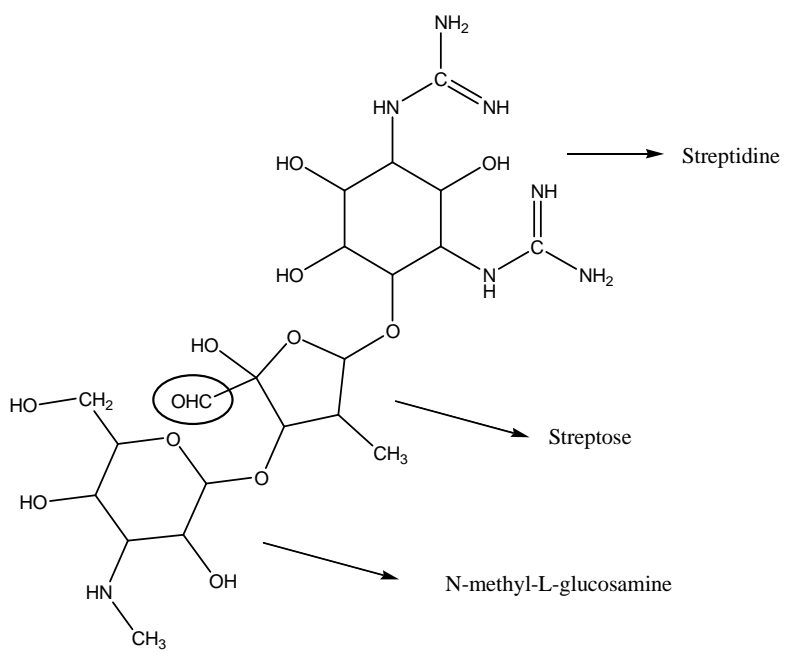

Figure 1. Structure of Streptomycin.

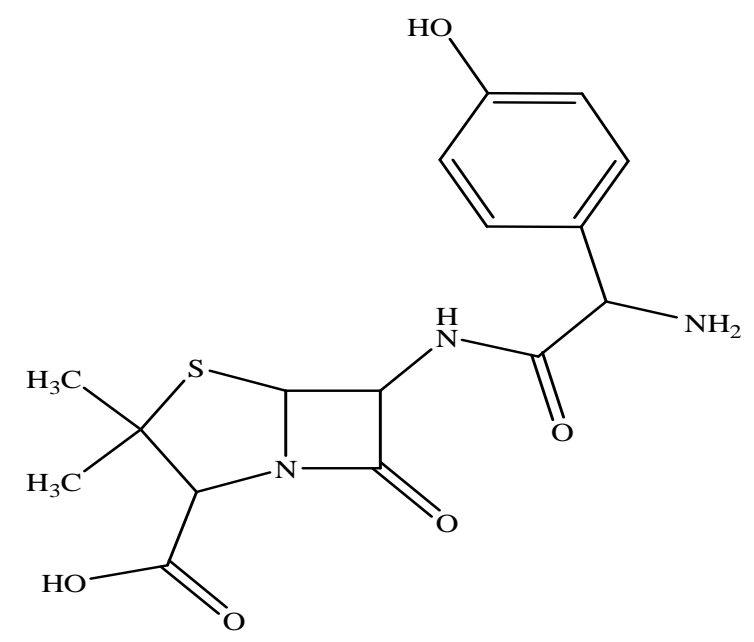

Figure 2. Structure of Amoxicillin.

\section{Experimental}

\subsection{Materials}

All the chemicals used were of analytical grade and were procured from local dealers of BDH, Merk \& Sigma Aldrich co. Chloride salts of Nickel, Copper and Zinc viz. $\mathrm{NiCl}_{2} \cdot 6 \mathrm{H}_{2} \mathrm{O}, \mathrm{CuCl}_{2} \cdot 2 \mathrm{H}_{2} \mathrm{O}$ and $\mathrm{ZnCl}_{2}$ were used as supplied for the synthesis of metal complexes of novel ligand. Distilled methanol mixed with double distilled water had been used as solvent for the synthesis.

\subsection{Instruments}

The elemental analysis $(\mathrm{C}, \mathrm{H}$ and $\mathrm{N})$ of the complexes were profound by using Elementar vario EL III (Germany) model. Characteristic shifts in IR band positions had been analyzed by intimate observations of infrared spectra of ligand and metal complexes that were run as $\mathrm{KBr}$ discs in the range $4000-400 \mathrm{~cm}^{-1}$ on a Shimadzu Infrared Spectrophotometer. ${ }^{1} \mathrm{HNMR}$ spectra were recorded in DMSO-d6 solvent on a Bruker advanced $400 \mathrm{MHz}$ instrument. Mass spectra were carried out TOF-MS on water KC-455 model in DMSO. The XRD powder pattern was recorded on a vertical type Philips 1130/00 x-ray diffractometer, operated at $40 \mathrm{kV}$ and $50 \mathrm{Ma}$ generators using the monochromitised $\mathrm{CuK} \alpha$ line at wavelength $1.54056 \AA$ as the radiation sources. Crystallographic data were analyzed by CRYSFIRE and CHECKCELL software programme. The molecular structures of the complexes were optimized by CsChem 3D Utra-11 programme.

\subsection{Synthesis and Characterization of Novel Schiff Base Ligand}

To the warm and homogenously stirred solution of alkaline ( $\mathrm{pH} 8$ ) Streptomycin sulphate (4 mmol, $2.718 \mathrm{gm}$ ) dissolved in $30 \mathrm{ml}$ aqueous methanol (1:1), was added a well stirred and hot solution of Amoxicillin trihydrate (4 mmol, $1.678 \mathrm{gm})$ dissolved in $30 \mathrm{ml}(1: 1)$ aqueous methanol. The $\mathrm{pH}$ of the solution was adjusted by adding $\mathrm{NaOH}$ solution. The mixture was stirred under heat on magnetic stirrer and was refluxed for $15 \mathrm{hrs}$ at $35^{\circ} \mathrm{C}$. The light orange colored solid was obtained by reducing its volume by placing over the hot plate. It was further recrystallized and dried under vacuum over anhydrous $\mathrm{CaCl}_{2}$.

Light Orange solid. Mol. wt. 928.96. Yield: (85\%, 3.158 gm), Anal. Cal. for $\mathrm{C}_{37} \mathrm{H}_{56} \mathrm{~N}_{10} \mathrm{O}_{16} \mathrm{~S}: \mathrm{C}, 47.839 ; \mathrm{H}, 6.08 ; \mathrm{N}$, 15.08; O, 27.56; S, 3.45. Found: C, 47.78; H, 6.12; N, 15.13; O, 27.60; S, 3.40\%. FTIR (KBr, $\left.\mathrm{cm}^{-1}\right) ; 1686.49$ (s, $\mathrm{vC}=\mathrm{N}$, azomethine); $1774.96 \quad(\mathrm{~s}, \quad \mathrm{C}=\mathrm{O}, \quad$ carboxylic $)$; 1588.99 (s, vC=O, lactam); 1144.48, 1120.44 (m, vC-O-C, glycosidic); 3462.11 (s,br, vO-H,); 1020.96 (C-O-C, cyclic ether); 1735.65, $1718.19(\mathrm{vC}=\mathrm{N}$, non azomethine $) ; 3178.66$ (s,br, vN-H str.); 3041.00 (vC-H, aromatic); 2970.10, 2928.09 ( $v$ C-H, methyl). ${ }^{1} \mathrm{H}$ NMR (in DMSO-d 6 solvent, $\delta$, ppm): 1.83-2.1 (alc. - $\mathrm{OH}, 7 \mathrm{H}$ ); 7.45 (imine $\mathrm{H}, 1 \mathrm{H}$ ); 7.59 $(\mathrm{N}-\mathrm{H}$ amide, $1 \mathrm{H}) ; 1.98-2.15(\mathrm{~N}-\mathrm{H}$ amine $) ; 1.2-2.5\left(\mathrm{CH}_{3}\right.$, 
12H); 6.5-6.91 (Ar-H, 4H); $10.89(\mathrm{COOH}) ; 3.0-5.46$ (cyclic $\mathrm{CH}, 16 \mathrm{H}) ; 5.4$ (Ph-OH, 1H); TOFMS: $m / z=928$

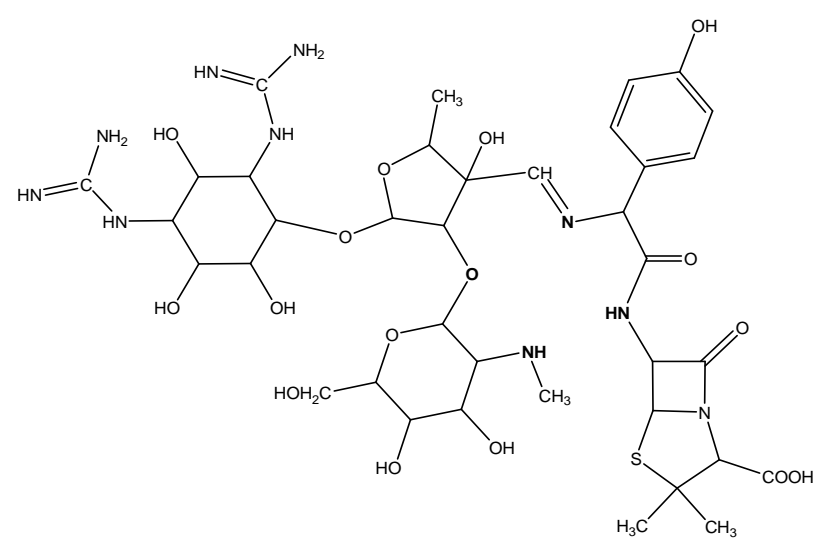

Figure 3. Proposed Structure of novel Schiff base ligand.

\subsection{Synthesis and Characterization of Metal Complexes}

To the hot and magnetically stirred $50 \mathrm{ml}(1: 1)$ aqueous methanolic solution of novel Schiff base ligand (0.4 mmol, ), was added $5 \mathrm{ml}$ methanolic solution of metal chloride salts. The mixture was then stirred and refluxed alternately at $45^{\circ} \mathrm{C}$ for another $15 \mathrm{hrs}$. On cooling, the precipitates of metal complexes of different colour were obtained, filtered and washed with methanol and dried over anhydrous $\mathrm{CaCl}_{2}$.

\subsubsection{Ni-Complex}

Yellow solid, M. Pt. $350^{\circ} \mathrm{C}$, Mol. wt. 985.65 . Yield: (78\%, 3.07 gm), Anal. Cal. for $\mathrm{C}_{37} \mathrm{H}_{54} \mathrm{~N}_{10} \mathrm{NiO}_{16} \mathrm{~S}: \mathrm{C}, 47.087 ; \mathrm{H}$, 5.52; N, 14.21; O, 25.97; S, 3.25; Ni, 5.95. Found: C, 47.14; H, 5.54; N, 14.18; O, 26.01; S, 3.21; Ni, 5.91\%. FTIR (KBr, $\left.\mathrm{cm}^{-1}\right) ; 1630.65(\mathrm{~s}, v \mathrm{C}=\mathrm{N}$, azomethine); 1136.11 (m, vC-O-C, glycosidic); 3462.11 (s,br, vO-H,); 1020.96 (C-O-C, cyclic ether); 3175.80 (s,br, vN-H str.); 503.12 (w, vNi-N); 435.14 (w, vNi-O). ${ }^{1} \mathrm{H}$ NMR (in DMSO-d ${ }_{6}$ solvent, $\delta, \mathrm{ppm}$ ): 8.34 (imine $\mathrm{H}$ ); 1.83-2.1 (alc. $-\mathrm{OH}, 7 \mathrm{H})$; 1.2-2.5 $\left(\mathrm{CH}_{3}, 12 \mathrm{H}\right)$; 6.5-6.91 (Ar-H, 4H); $10.89(\mathrm{COOH}) ; 3.0-5.46$ (cyclic $\mathrm{CH}$, $16 \mathrm{H}) ; 5.4$ (Ph-OH, 1H); TOFMS: $m / z=984$.

\subsubsection{Cu-Complex}

Gray solid, M. Pt. $320^{\circ}$ C, Mol. wt. 990.49. Yield: (80\%, 3.16 gm), Anal. Cal. for $\mathrm{C}_{37} \mathrm{H}_{54} \mathrm{CuN}_{10} \mathrm{O}_{16} \mathrm{~S}$ : C, 44.867; $\mathrm{H}$, 5.50; N, 14.14; O, 25.84; S, 3.24; Cu, 6.42. Found: C, $44.81 ; \mathrm{H}, 5.53 ; \mathrm{N}, 14.18 ; \mathrm{O}, 25.78 ; \mathrm{S}, 3.18, \mathrm{Cu}, 6.38 \%$. FTIR $\left(\mathrm{KBr}, \mathrm{cm}^{-1}\right) ; 1628.44(\mathrm{~s}, \mathrm{vC}=\mathrm{N}$, azomethine); 1130.06 (m, vC-O-C, glycosidic); 3462.11 (s,br, vO-H,); 1020.96 (C-O-C, cyclic ether); 3172.75 (s,br, vN-H str.); 495.00 $(v \mathrm{Cu}-\mathrm{N}) ; 428.58(\mathrm{vCu}-\mathrm{O}) .{ }^{1} \mathrm{H}$ NMR (in DMSO-d ${ }_{6}$ solvent, $\delta$, ppm): 8.15 (imine $\mathrm{H}$ ); 1.83-2.1 (alc. $-\mathrm{OH}, 7 \mathrm{H}$ ); 1.2-2.5 $\left(\mathrm{CH}_{3}, 12 \mathrm{H}\right)$; 6.5-6.91 (Ar-H, 4H); 10.89 (COOH); 3.0-5.46 (cyclic $\mathrm{CH}, 16 \mathrm{H}) ; 5.4(\mathrm{Ph}-\mathrm{OH}, 1 \mathrm{H})$; TOFMS: $m / z=989$.

\subsubsection{Zn-Complex}

Crimson solid, M. Pt. $305^{\circ} \mathrm{C}$, Mol. wt. 992.34. Yield: (75\%, $2.97 \mathrm{gm})$, Anal. Cal. for $\mathrm{C}_{37} \mathrm{H}_{54} \mathrm{~N}_{10} \mathrm{O}_{16} \mathrm{SZn}: \mathrm{C}$, 44.783; H, 5.48; N, 14.11; O, 25.80; S, 3.23; Zn, 6.59.
Found: C, 44.75; H, 5.51; N, 14.08; O, 25.78; S, 3.19, Zn, $6.61 \%$. FTIR $\left(\mathrm{KBr}, \mathrm{cm}^{-1}\right) ; 1622.61$ ( $\mathrm{s}, \mathrm{vC}=\mathrm{N}$, azomethine); 1135.65 (m, vC-O-C, glycosidic); 3462.11 (s,br, vO-H,); 1020.96 (C-O-C, cyclic ether); 3176.30 (s,br, vN-H str.); 480.75 (vZn-N); 432.00 (vZn-O). ${ }^{1} \mathrm{H}$ NMR (in DMSO-d solvent, $\delta$, ppm): 7.89 (imine $\mathrm{H}$ ); 1.83-2.1 (alc. $-\mathrm{OH}, 7 \mathrm{H}$ ); 1.2-2.5 $\left(\mathrm{CH}_{3}, 12 \mathrm{H}\right)$; 6.5-6.91 (Ar-H, 4H); 10.89 (COOH); 3.0-5.46 (cyclic $\mathrm{CH}, 16 \mathrm{H})$; $5.4(\mathrm{Ph}-\mathrm{OH}, 1 \mathrm{H})$; TOFMS: $\mathrm{m} / \mathrm{z}$ $=990$.

\subsection{Antibacterial Study}

In vitro antibacterial assay of novel ligand conjugated with different metals was studied by Kirby Bauer paper disc diffusion method [14, 15], using Mueller-Hinton's agar nutrient media and maintaining $\mathrm{pH}$ at 7.4 for better bacterial growth. Fresh cultures of standard bacteria viz. $E$. coli, B. subtilis, S. aureus and Klebsiella pneumoniea were collected from microbiology lab. of KIST medical college, Kathmandu, Nepal and well isolated colonies of the selected bacterial pathogens were cultured in tryptic soy broth. The inoculums was spread over nutrient agar media, prepared as usual in Petri plates using stick swab and the well sterilized Paper discs of $6 \mathrm{~mm}$ diameter (Whatman no. 1) impregnated with test compounds at the concentration of $0.001 \mathrm{~g} / \mathrm{ml}$ in DMSO were placed on the previously seeded bacterial culture. Amoxicillin 10 microgram disc of $6 \mathrm{~mm}$ size (HIMEDIA co.) was used as standard (+ve control). DMSO, which exhibited no antimicrobial activity against the test bacterial pathogens, was used as negative control. Afterwards, the Petri plates were incubated at $37^{\circ} \mathrm{C}$ and the diameter of zone of inhibition around each disc was measured after overnight of incubation.

\section{Results and Discussion}

\subsection{Infrared Spectral Analysis}

The IR spectral comparision of the novel ligand and its metal complexes had been used to ascertain the binding mode of the metal ions at donor sites of the ligand. Shift in the positions of strong intensity band at $1686.49 \mathrm{~cm}^{-1}$ characteristic for azomethine $\mathrm{C}=\mathrm{N}$ stretch in Schiff base ligand to lower wave numbers 1630.65, 1628.44 and $1622.61 \mathrm{~cm}^{-1}$ for $\mathrm{Ni}, \mathrm{Cu}$ and $\mathrm{Zn}$ complexes respectively supported the coordination of the azomethine nitrogen to the metal centers. This fact was further substantiated by the appearance of a new band around $500 \mathrm{~cm}^{-1}$ assignable for $v_{\mathrm{M}-\mathrm{N}}$ vibration. The negative band shift from $3178.66 \mathrm{~cm}^{-1}$ assignable for N-H stretch in ligand was in good agreement for the coordination of metal ions with deprotonated nitrogen of amine group. Glycosidic C-O-C asymmetric and symmetric stretch at 1144.48 and $1120.44 \mathrm{~cm}^{-1}$ in ligand have also changed to lower wave number, indicating metal-oxygen binding mode. Additional information regarding the coordination of metal ions with oxygen was appearance of medium intensity band in the region of 440 $430 \mathrm{~cm}^{-1}$ assignable to $v_{\mathrm{M}-\mathrm{O}}$ stretching vibration. A strong 
sharp band observed at $1588.99 \mathrm{~cm}^{-1}$ assignable for $\mathrm{v}(\mathrm{C}=\mathrm{O})$ lactam was restored in the metal complexes.

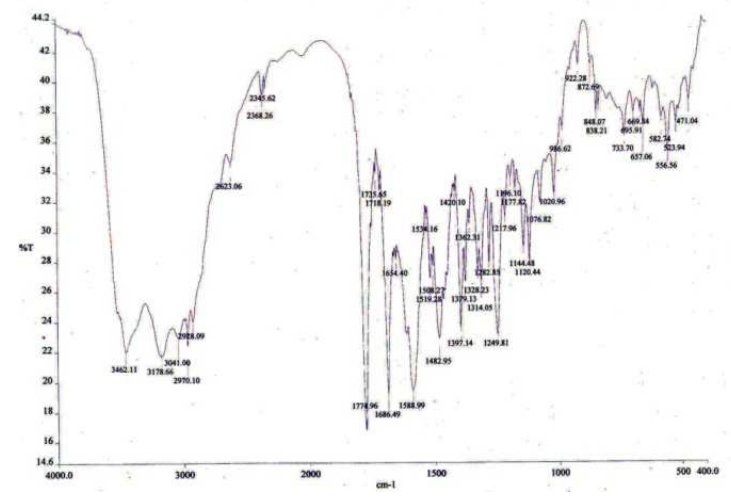

Figure 4. IR spectra of novel ligand.

\section{2. ${ }^{1}$ H NMR Spectral Analysis}

${ }^{1} \mathrm{H}$ NMR spectral comparison of novel Schiff base ligand and its metal complexes was made to confirm the binding nature of ligand with metal ions viz. $\mathrm{Ni}(\mathrm{II}), \mathrm{Cu}(\mathrm{II})$ and $\mathrm{Zn}(\mathrm{II})$. The integral intensities of each signal in the ${ }^{1} \mathrm{H}$ NMR spectra of ligand and metal ion complexes were found to agree with the number of different types of protons present. The formation of Schiff base was confirmed by extinction of aldehyde proton at $7.52 \mathrm{ppm}$ and the appearance of imine proton signal at $7.45 \mathrm{ppm}$ with reference to $\mathrm{DMSO}^{-\mathrm{d}_{6}}$ in ${ }^{1} \mathrm{H}$ NMR spectra. The coordination of imino group to the metal ions was confirmed by the change of chemical shift of the imine proton from 7.14 to $8.434 \mathrm{ppm}$ on complexation with considered metal ions.

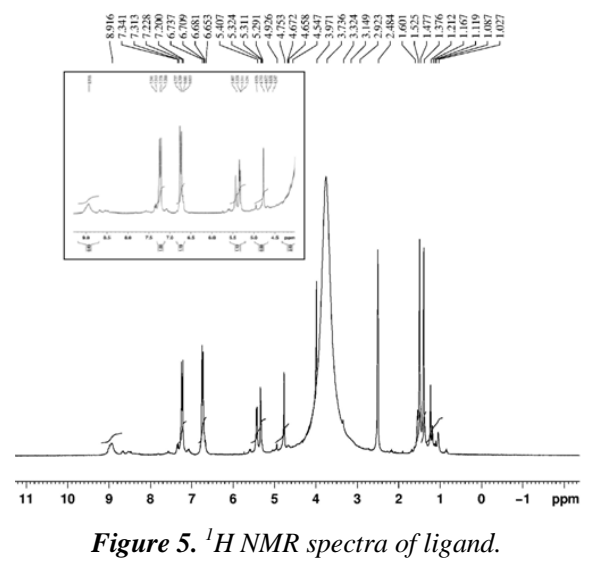

\subsection{Electronic Spectra}

The room temperature magnetic susceptibility data of the Ni-complex revealed that, the complex is essentially diamagnetic and of low spin with ${ }^{1} \mathrm{~A}_{1 \mathrm{~g}} \rightarrow{ }^{1} \mathrm{~A}_{2 \mathrm{~g}} \rightarrow{ }^{1} \mathrm{E}_{\mathrm{g}}$ transitions respectively. The complex is therefore, said to have square planar geometry. It was diamagnetic and there was no band seen below $1000 \mathrm{~nm}$. The observed $\mu_{\text {eff. }} 1.81$ $\mathrm{BM}$ of the $\mathrm{Cu}$-complex was very close to the spin only value of an unpaired electron (1.73 BM) which indicated that the orbital contribution is almost quenched by the crystal field. Electronic spectra of the complex showed only three bands in the region 540-450 nm due to transition ${ }^{2} \mathrm{~B}_{1 \mathrm{~g}} \rightarrow \mathrm{A}_{1 \mathrm{~g}} \rightarrow{ }^{1} \mathrm{E}_{\mathrm{g}}$ and charge transfer respectively which corresponds to tetrahedral geometry. The Zn complex was diamagnetic and had a square planar structure as confirmed by its electronic transition spectra.

\subsection{Molar Conductivity}

The molar conductivity $\left(\Lambda_{\mathrm{M}}\right)$ data $\left(1.5-5.8 \Omega^{-1} \mathrm{~mol}^{-1} \mathrm{~cm}^{-1}\right)$ were measured at $25^{\circ} \mathrm{C}$ using $10^{-3} \mathrm{M}$ solutions of the complexes in $\mathrm{CHCl}_{3}$ solvent. These values revealed that all the complexes are non-electrolyte due to the absence of any counter ion in the complexes. The molar conductance values of these complexes indicated that the novel Schiff base ligand was coordinated to the $\mathrm{Ni}(\mathrm{II}), \mathrm{Cu}$ (II) and $\mathrm{Zn}$ (II) ions as a doubly negative charged anions. Therefore it seems that the two amino (-NH) have been deprotonated and bonded to the metal ions as nitrogen anions.

\subsection{X-Ray Powder Diffraction Study}

Single crystal growth of the complexes had been failed, so X-ray powder diffraction technique was carried to get useful crystal data to deduce accurate cell parameters, crystal system and the cell volume. Powder diffraction patterns of ligand and metal complexes were recorded and crystallographic data are listed in the table. The diffraction pattern reveals the crystalline nature of the complex and the data confirmed the monoclinic crystal system for $\mathrm{Ni}$ and $\mathrm{Zn}$ complexes. Similarly hexagonal crystal system had been achieved for $\mathrm{Cu}$ complex.

Table 1. Crystal Lattice Parameters of ligand and Metal Complexes.

\begin{tabular}{|c|c|c|c|c|}
\hline Compounds & Ligand & $\begin{array}{c}\text { Ni- } \\
\text { Complex }\end{array}$ & $\begin{array}{c}\mathrm{Cu}- \\
\text { Complex }\end{array}$ & $\begin{array}{c}\text { Zn- } \\
\text { Complex }\end{array}$ \\
\hline Formula & $\begin{array}{l}\mathrm{C}_{37} \mathrm{H}_{56} \mathrm{~N}_{1} \\
{ }_{0} \mathrm{O}_{16} \mathrm{~S}\end{array}$ & $\begin{array}{l}\mathrm{C}_{37} \mathrm{H}_{54} \mathrm{~N}_{10} \mathrm{~N} \\
\mathrm{iO}_{16} \mathrm{~S}\end{array}$ & $\begin{array}{l}\mathrm{C}_{37} \mathrm{H}_{54} \mathrm{CuN}_{10} \\
\mathrm{O}_{16} \mathrm{~S}\end{array}$ & $\begin{array}{l}\mathrm{C}_{37} \mathrm{H}_{54} \mathrm{~N}_{10} \mathrm{O} \\
{ }_{16} \mathrm{SZn}\end{array}$ \\
\hline FW & 928.96 & 985.65 & 990.49 & 992.34 \\
\hline Temp (K) & 293 & 293 & 293 & 293 \\
\hline Wavelength & 1.54056 & 1.54056 & 1.54056 & 1.54056 \\
\hline $\begin{array}{l}\text { Crystal } \\
\text { System }\end{array}$ & $\begin{array}{l}\text { Tetragon } \\
\text { al }\end{array}$ & Monoclinic & Hexagonal & Monoclinic \\
\hline $\begin{array}{l}\text { Space group } \\
\text { Unit cell dime }\end{array}$ & $\mathrm{P} / \mathrm{mmm}$ & $\mathrm{P} 2 / \mathrm{m}$ & $\mathrm{P} 6 / \mathrm{mmm}$ & $\mathrm{P} 121 / \mathrm{m} 1$ \\
\hline $\mathrm{a}(\check{\mathrm{A}})$ & 12.717 & 1.8527 & 24.7801 & 13.211 \\
\hline $\mathrm{b}(\tilde{\mathrm{A}})$ & 12.717 & 11.4297 & 11.771 & 8.5631 \\
\hline$c(\AA)$ & 16.652 & 8.7017 & 9.2018 & 9.2018 \\
\hline$\alpha^{0}$ & 90.00 & 90.00 & 90.00 & 90.00 \\
\hline$\beta^{\text {o }}$ & 90.00 & 97.198 & 90.00 & 91.226 \\
\hline & 90.00 & 90.00 & 90.00 & 90.00 \\
\hline Volume $\left(\mathrm{A}^{3}\right)$ & 2693.37 & 1465.683 & 2678.61 & 1085.76 \\
\hline$\theta$ range $(0)$ & $\begin{array}{l}21.696- \\
75.106\end{array}$ & $\begin{array}{l}13.811- \\
61.987\end{array}$ & $10-65$ & $12-67$ \\
\hline $\begin{array}{l}\text { Limiting } \\
\text { indices }\end{array}$ & $\begin{array}{l}0 \leq \mathrm{h} \leq 4 \\
0 \leq \mathrm{k} \leq 6 \\
0 \leq 1 \leq 3\end{array}$ & $\begin{array}{l}-6 \leq \mathrm{h} \leq 4 \\
0 \leq \mathrm{k} \leq 7 \\
0 \leq 1 \leq 4\end{array}$ & $\begin{array}{l}-10 \leq \mathrm{h} \leq 6 \\
0 \leq \mathrm{k} \leq 1 \\
0 \leq 1 \leq 5\end{array}$ & $\begin{array}{l}-1 \leq \mathrm{h} \leq 3 \\
-4 \leq \mathrm{k} \leq 5 \\
0 \leq 1 \leq 7\end{array}$ \\
\hline $\begin{array}{l}\text { Particle } \\
\text { size(nm) }\end{array}$ & 11.922 & 80.82 & 55.99 & 10.92 \\
\hline $\begin{array}{l}\text { Intensity } \\
(\%)\end{array}$ & $7.2-100$ & $5.9-100$ & $4.5-100$ & $3.4-100$ \\
\hline $\mathrm{R}$ indices & $\begin{array}{l}0.000015 \\
6\end{array}$ & 0.0000615 & 0.0000754 & 0.0000362 \\
\hline $\begin{array}{l}\text { Density } \\
\mathrm{Z}\end{array}$ & $\begin{array}{l}1.07405 \\
2\end{array}$ & $\begin{array}{l}1.7437 \\
2\end{array}$ & $\begin{array}{l}1.034 \\
1\end{array}$ & $\begin{array}{l}1.151 \\
1\end{array}$ \\
\hline
\end{tabular}




\subsection{Thermal Decomposition Kinetics}

The thermodynamic and kinetic parameters for the nonisothermal decomposition of the complexes such as order of reaction $(n)$, enthalpy change $\left(\Delta H^{*}\right)$, activation energy $\left(E^{*}\right)$, entropy change $\left(\Delta S^{*}\right)$ and Gibb's free energy change $\left(\Delta \mathrm{G}^{*}\right)$ were evaluated by thermo gravimetric (DT) and differential thermo gravimetric (DTA) analysis. Thermo gravimetric analysis data for the metal complexes revealed that nearly $15 \%$ of the total mass of the $\mathrm{Ni}$ and $\mathrm{Cu}-$ complexes reduced between $75^{\circ} \mathrm{C}$ and $240^{\circ} \mathrm{C}$, followed by considerable decomposition up to $600^{\circ} \mathrm{C}$ that corresponds to the decomposition of the ligand leaving metal oxide, $\mathrm{NiO}$ and $\mathrm{CuO}$ respectively as residue. Zn-complex decomposed nearly $9 \%$ of the total mass up to the temperature $160^{\circ} \mathrm{C}$ followed by considerable decomposition of its ligand up to $550^{\circ} \mathrm{C}$, leaving $\mathrm{ZnO}$ as residue. These decomposition patterns were in good agreement with suggested formulae of the complexes. By the analysis of the non-isothermal TG, using the integral method of CoatsRedfern relation $[16,17,18]$, kinetic parameters of decomposition were calculated.

$$
\ln \left[-\frac{\ln (1-\alpha)}{\mathrm{T}^{2}}\right]=\ln \left[\frac{\mathrm{AR}}{\varphi \mathrm{E}^{*}}\right]-\frac{\mathrm{E}^{*}}{\mathrm{RT}}
$$

Where $\alpha$ is the mass loss up to the temperature T, R is the gas constant, $\mathrm{E}^{*}$ is the activation energy in $\mathrm{J}$ mole $^{-1}$ and $\varphi$ is the linear heating rate. A straight line plot of left hand side of the equation against $1 / \mathrm{T}$ gave a slop from which $\mathrm{E}^{*}$ was calculated while its intercept value corresponds to frequency factor (A). The entropy of activation $\Delta \mathrm{S}^{*}$ in $\mathrm{J} \mathrm{K}^{-1}$ $\mathrm{mol}^{-1}$, enthalpy change $\left(\Delta \mathrm{H}^{*}\right)$ and Gibb's free energy change $\left(\Delta \mathrm{G}^{*}\right)[19]$ were calculated by using the equations:

$$
\begin{gathered}
\Delta \mathrm{S}^{*}=\mathrm{R} \ln \left[\frac{\mathrm{A} h}{\mathrm{k}_{\mathrm{B}} \mathrm{T}}\right] \\
\Delta \mathrm{H}^{*}=\mathrm{E}^{*}-\mathrm{RT} \\
\Delta \mathrm{G}^{*}=\Delta \mathrm{H}^{*}-\mathrm{T} \Delta \mathrm{S}^{*}
\end{gathered}
$$

Where, $k_{B}$ is the Boltzmann constant, $h$ the plank's constant and T is the DTG peak temperature.

The Coats-Redfern linearization plots, confirmed the first order kinetics for the decomposition process. The calculated values of thermodynamic activation parameters for the decomposition steps of the metal complexes are reported in Table 4. According to the kinetic data obtained from the TG curves, the activation energy relates the thermal stability of the metal complexes. Among metal complexes, activation energy increases as complex $2<$ complex $3<$ complex 1 . Same trends happen with thermal stability of metal complexes. Negative entropy values of all the complexes indicated that the complexes were formed spontaneously. It also indicated a more ordered activated state that may be possible through the chemisorptions of oxygen and other decomposition products. These negative entropy values of activation are compensated by the values

\begin{tabular}{|c|c|c|c|c|c|c|c|c|c|}
\hline Complex & Order/n & $\begin{array}{l}\text { Step } \\
\text { s }\end{array}$ & $\mathrm{E}^{*} / \mathrm{Jmol}^{-1}$ & $\mathrm{~A} / \mathrm{sec}^{-1}$ & $\Delta \mathrm{S}^{*} / \mathrm{J} \mathrm{K}^{-1} \mathrm{~mol}^{-1}$ & $\Delta \mathbf{H}^{*} / \mathrm{J} \mathrm{mol}^{-1}$ & $\begin{array}{ll}\Delta \mathbf{G}^{*} / & \mathbf{k J} \\
\mathbf{m o l}^{-1} & \\
\end{array}$ & $k \times 10^{2} s^{-1}$ & $\begin{array}{l}\text { Thermal } \\
\text { effect }\end{array}$ \\
\hline \multirow{2}{*}{$\mathrm{C}_{37} \mathrm{H}_{54} \mathrm{~N}_{10} \mathrm{NiO}_{16} \mathrm{~S}$} & \multirow{2}{*}{1} & $\mathrm{I}$ & 48.05 & $0.235 \times 10^{5}$ & -91.49 & 120.65 & 93.33 & 1.17 & Endo. \\
\hline & & II & 114 & $0.428 \times 10^{5}$ & -363.33 & 75.89 & 25.43 & 1.41 & Exo. \\
\hline \multirow{2}{*}{$\mathrm{C}_{37} \mathrm{H}_{54} \mathrm{CuN}_{10} \mathrm{O}_{16} \mathrm{~S}$} & \multirow{2}{*}{1} & I & 16.58 & $2.38 \times 10^{5}$ & -305.74 & 114.75 & 121.81 & 4.62 & Exo. \\
\hline & & II & 23.35 & $1.365 \times 10^{5}$ & -114.81 & 235.53 & 926.98 & 1.13 & Exo. \\
\hline \multirow{2}{*}{$\mathrm{C}_{37} \mathrm{H}_{54} \mathrm{~N}_{10} \mathrm{O}_{16} \mathrm{SZn}$} & \multirow{2}{*}{1} & I & 31.42 & $1.25 \times 10^{5}$ & -67.345 & 125.41 & 37.22 & 1.98 & Exo. \\
\hline & & II & 32.21 & $3.21 \times 10^{4}$ & -94.96 & 140.35 & 48.34 & 2.21 & Endo. \\
\hline
\end{tabular}
of the enthalpies of activation, leading to almost the same values for the free energy of activation.

Table 2. Thermodynamic activation parameters of the metal complexes.

\subsection{Antibacterial Activity}

In vitro antibacterial screening of the ligand and the metal complexes was assayed against various bacterial strains and the potentiality of the complexes was evaluated by measuring the diameter of zone of inhibition in $\mathrm{mm}$. The prescription of the antimicrobial results showed graphically, revealed that both free ligand and its metal complexes exhibited moderate to better antibacterial activity. Such increased activity of metal complexes may be considered due to chelation of metal ions with Schiff base with enhanced lipophilicity due to delocalization of pi-electrons over the whole chelate ring. This increased lipophilicity enhances the penetration of complexes into the lipid membranes and blocks the metal binding sites in enzymes of microorganisms [20, 21]. These complexes also disturb the respiration process of the cell and thus block the synthesis of proteins, which restricts further growth of the organism. The data revealed that the activity of the ligand enhanced on complexation comparable to the standard used. Overall comparison of observed data gave information that metal complexes are more active than free ligand against all bacteria.

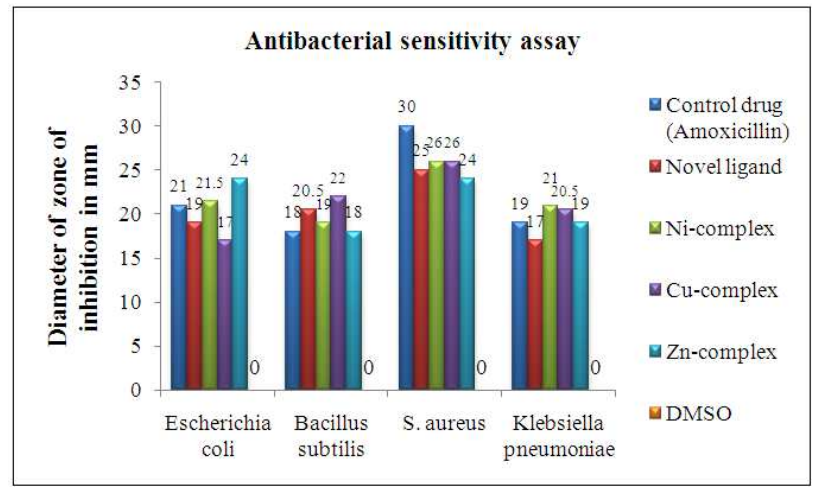

Figure 6. Comparative antibacterial potency of synthesized compounds with standard drug. 

derived from Streptomycin and Amoxicillin: Synthesis, Characterization and Molecular Modelling

Concentration of sample $=0.001 \mathrm{~g} / \mathrm{ml}$ of DMSO

Concentration of control drug $=10 \mu \mathrm{g} / \mathrm{disc}$.

(0) = No sensitivity

Zone of inhibition (mm): 20 or $>20$ sensitive

\section{Molecular Modeling Study}

3D molecular modeling of the proposed structure of the metal complexes was studied by CsChem 3D Ultra program package and revealed tetrahedral geometry for $\mathrm{Cu}$ complex and square planar geometry for $\mathrm{Ni}$ and $\mathrm{Zn}$ - complexes [22]. The correct stereochemistry was assured through, manipulation and modification of the molecular coordinates to obtain reasonable and low energy molecular geometries. Energy minimization was repeated several times to find the minimum [23]. The change in bond length values of metal-nitrogen and metal-oxygen in the complexes compared with ligand further suggest their coordination. The details of the bond lengths and bond angles as per 3D structure of the metal complexes optimized by MM2 calculations are given in the table.

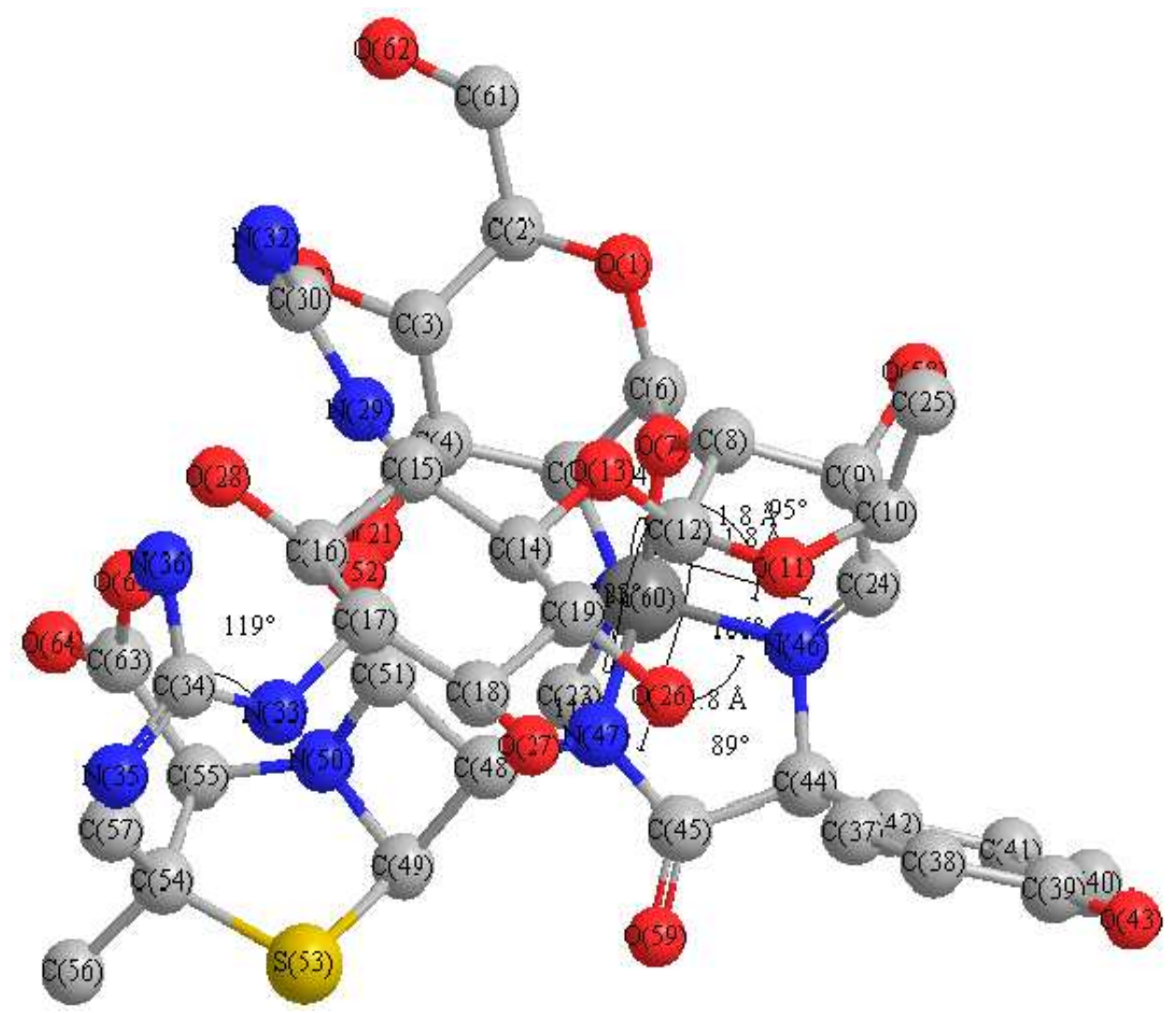

Figure 7. Optimized Structure of Nickel complex.

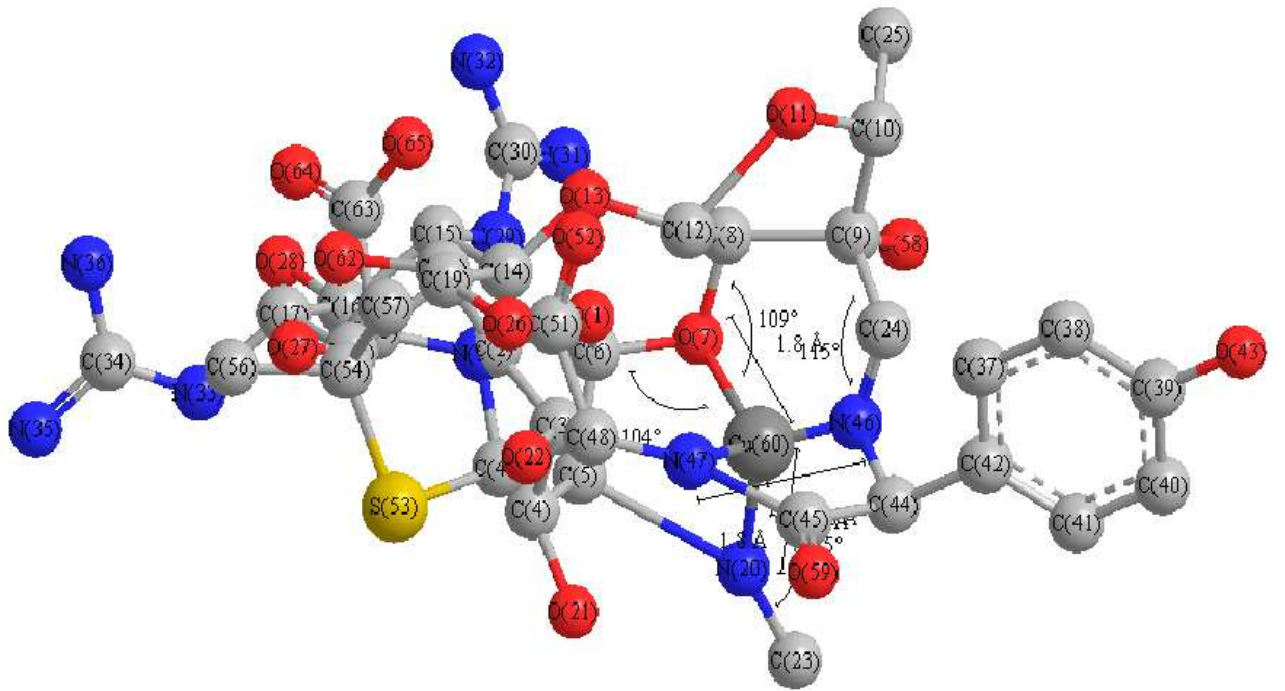

Figure 8. Optimized Structure of Copper complex. 


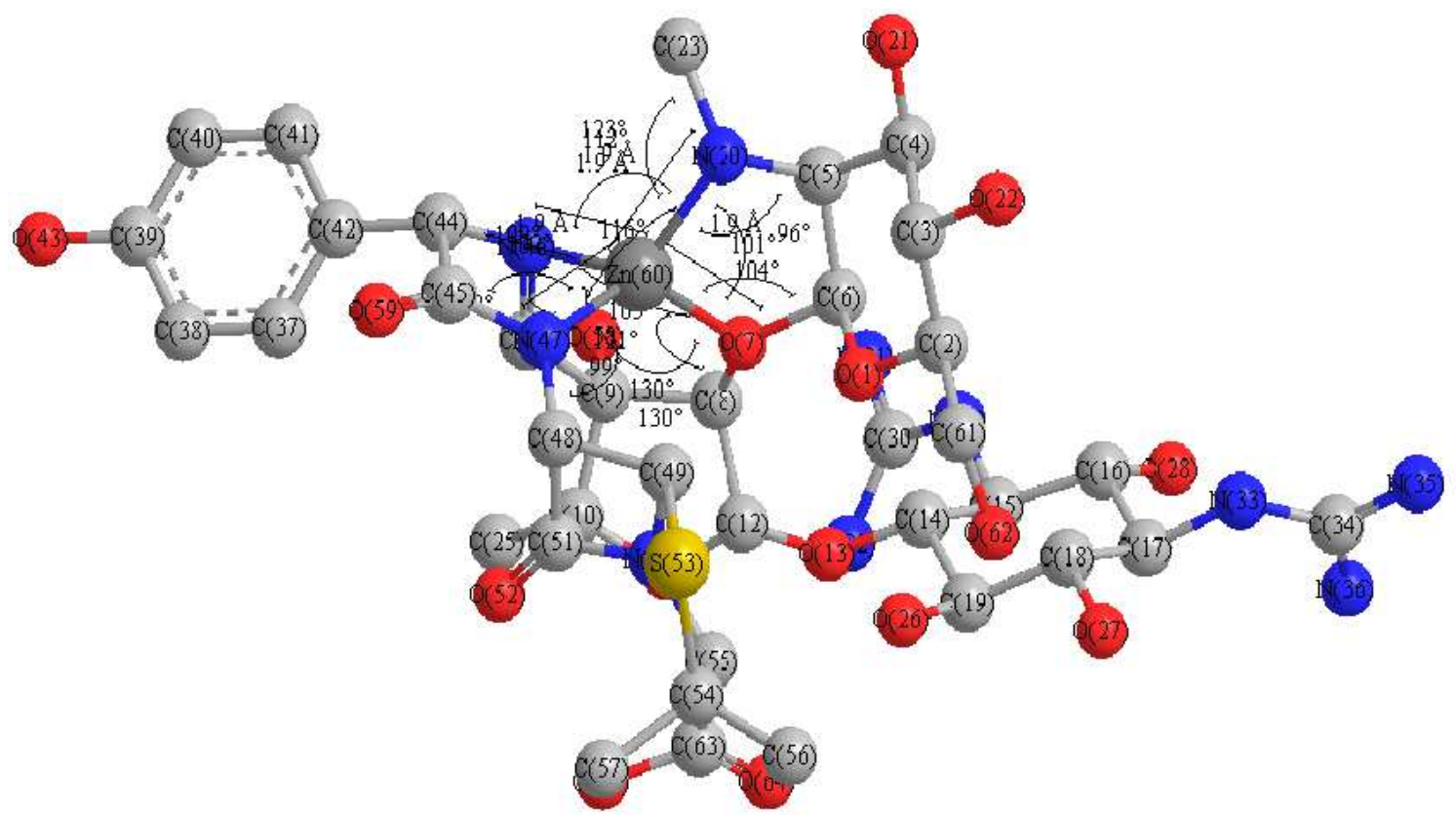

Figure 9. Optimized Structure of Zinc complex.

Table 3. Bond length and bond angle results of metal complexes.

\begin{tabular}{|c|c|c|c|c|c|}
\hline \multicolumn{2}{|l|}{ Nickel Complex } & \multicolumn{2}{|l|}{ Copper Complex } & \multicolumn{2}{|l|}{ Zinc Complex } \\
\hline Bond lengths & & Bond lengths & & Bond lengths & \\
\hline N(46)-Ni(60) & 1.8302 & $\mathrm{~N}(46)-\mathrm{Cu}(60)$ & 1.3030 & $N(46)-Z n(60)$ & 1.9352 \\
\hline $\mathrm{O}(7)-\mathrm{Ni}(60)$ & 1.8039 & $\mathrm{Cu}(60)-\mathrm{N}(47)$ & 1.8460 & $\mathrm{O}(7)-\mathrm{Zn}(60)$ & 1.9275 \\
\hline N(47)-Ni(60) & 1.8166 & $\mathrm{Cu}(60)-\mathrm{N}(20)$ & 1.8460 & $\mathrm{~N}(47)-\mathrm{Zn}(60)$ & 1.9293 \\
\hline Bond angles & & $\mathrm{O}(7)-\mathrm{Cu}(60)$ & 1.8100 & $\mathrm{~N}(20)-\mathrm{Zn}(60)$ & 1.9300 \\
\hline $\mathrm{N}(47)-\mathrm{Ni}(60)-\mathrm{N}(46)$ & 88.9349 & Bond angles & & Bond angles & \\
\hline $\mathrm{N}(47)-\mathrm{Ni}(60)-\mathrm{N}(20)$ & 119.1831 & $\mathrm{Cu}(60)-\mathrm{O}(7)-\mathrm{C}(8)$ & 109.5000 & $\mathrm{Zn}(60)-\mathrm{N}(47)-\mathrm{C}(48)$ & 129.7704 \\
\hline $\mathrm{N}(47)-\mathrm{Ni}(60)-\mathrm{O}(7)$ & 123.3601 & $\mathrm{Cu}(60)-\mathrm{O}(7)-\mathrm{C}(6)$ & 104.0000 & $\mathrm{Zn}(60)-\mathrm{N}(47)-\mathrm{C}(45)$ & 108.5763 \\
\hline $\mathrm{N}(46)-\mathrm{Ni}(60)-\mathrm{N}(20)$ & 106.4453 & $\mathrm{~N}(46)-\mathrm{C}(24)-\mathrm{C}(9)$ & 115.1000 & $\mathrm{Zn}(60)-\mathrm{N}(46)-\mathrm{C}(24)$ & 99.1209 \\
\hline $\mathrm{N}(46)-\mathrm{Ni}(60)-\mathrm{O}(7)$ & 94.7126 & $\mathrm{Cu}(60)-\mathrm{N}(20)-\mathrm{C}(23)$ & 145.4178 & $\mathrm{Zn}(60)-\mathrm{N}(46)-\mathrm{C}(44)$ & 101.5375 \\
\hline $\mathrm{N}(20)-\mathrm{Ni}(60)-\mathrm{O}(7)$ & 113.6983 & $\mathrm{Cu}(60)-\mathrm{N}(20)-\mathrm{C}(5)$ & 69.1644 & $\mathrm{Zn}(60)-\mathrm{N}(20)-\mathrm{C}(23)$ & 111.9931 \\
\hline & & & & $\mathrm{Zn}(60)-\mathrm{N}(20)-\mathrm{C}(5)$ & 104.0956 \\
\hline
\end{tabular}

\section{Conclusion}

We have successfully synthesized metal $\mathrm{Ni}(\mathrm{II}), \mathrm{Cu}(\mathrm{II}) \&$ $\mathrm{Zn}$ (II)-complexes of novel Schiff base ligand derived from Streptomycin and Amoxicillin. Spectral, thermal and other analytical data revealed the real correlation with the proposed and suggested structure. Molar conductivity measurement recommended non electrolytic nature of the complexes. Further, molecular modeling and electronic spectral data measurement strongly recommend tetrahedral geometry of $\mathrm{Cu}$-complex and square planar geometry for $\mathrm{Ni}$ and $\mathrm{Zn}$-complexes. Negative entropy values obtained by thermal decomposition calculations, using Coats-Redfern equation indicated the spontaneous formation of metal complexes. The two antibiotics in conjugation with metals lead to better antibiotic activities. The antibacterial screening of the synthesized ligand and its metal complexes against various pathogenic bacteria suggested improved antibacterial activities. Comparable antibacterial sensitivity test of the ligand and metal complexes showed that they bear strong activity against $\mathrm{S}$. aureus.

\section{Acknowledgements}

We would like to acknowledge KIST medical college, Kathmandu for assisting in antibacterial sensitivity study by providing fresh cultures of bacterial pathogens. We are also grateful to (USIC) Delhi University, India, for immense support in spectral studies.

\section{References}

[1] J. Berdy, "Thoughts and facts about antibiotics: Where we are now and where we are heading" J Antibiot. 2012: 65: 385-395. doi: 10.1038/ja.2012.27.

[2] M. S. Butler, M. A. Blaskovich, M. A. Cooper, "Antibiotics in the clinical pipeline in 2013" J Antibiot. 2013: 66: 571591. doi: 10.1038/ja.2013.86.

[3] M. Frezza, S. Hindo, D. Chen, A. Davenport, S. Schmitt, D. Tomco, Q. P. Dou, "Novel Metals and Metal complexes as Platforms for Cancer Therapy" Curr Pharm des. 2010: 16(16): 1813-1825. 
[4] A. Kajal, S. Bala, S. Kamboj, N. Sharma, V. Saini, "Schiff Bases: A Versatile Pharmacophore" Journal of Catalysis. 2013, http://dx.doi.org/10.1155/2013/893512.

[5] M. A. Bhat, M. A. Al-Omar, "Synthesis, Characterization, and in vitro anti-Mycobacterium tuberculosis activity of terpene Schiff bases" Medicinal chemistry Research. 2013: 22(9): 4522-4528. doi 10.1007/s00044-012-0458-3.

[6] A. Chakraborty, P. Kumar, K. Ghosh, P. Roy, "Evaluation of a Schiff base copper complex compound as potential anticancer molecule with multiple targets of action" European Journal of Pharmacology. 2010: 647(1): 1-12.

[7] R. P. Chinnasamy, R. Sundararajan, S. Govindaraj, "Synthesis, characterization and analgesic activity of novl Schiff base of isatin derivatives" J Adv Pharm Technol Res. 2010: 1(3): 342-347. doi: 10.4103/0110-5558.72428.

[8] E. Pontiki, D. Hadjipavlou-Litina, A. T. Chaviara, "Evaluation of anti-inflammatory and antioxidant activities of Copper (II) Schiff mono-base and Copper (II) Schiff base coordination compounds of dien with heterocyclic aldehydes and 2-amino-5-methyl-thiazole" J Enzyme Inhib Med Chem. 2008: 23(6): 1011-1017. doi: $10.1080 / 14756360701841251$.

[9] S. Garg, P. Attri, K. Sharma, R. Ranjan, P. Mishra, "In-vitro cell viability and Antibacterial activity of novel Bismuth (V) complex" International journal of PharmTech Research. 2009: 1(4): 1685-1691.

[10] C. Lienhardt, M. Raviglione, M. Spigelman, R. Hafner, E. Jaramillo, M. Hoelscher, A. Zumla, J. Gheuens, "New Drugs for the Treatment of Tuberculosis: Needs, Challenges, Promise, and Prospects for the Future" Journal of Infectious Diseases. (Advance Access published): 2012: doi: 10.1093/infdis/jis034.

[11] N. Honore, S. T. Cole, "Streptomycin Resistance in Mycobacteria" Antimicrob. Agents Chemother. 1994: 38(2): 238. doi: 10.1128/AAC.38.2.238

[12] S. Kalkandelen, E. Selimoglu, F. Erdogan, H. Ucuncu, E. Altas, "Comparative Cochlear Toxicities of Streptomycin, Gentamicin, Amikacin and Netilmicin in Guinea-pigs" Journal of International Medical Research. 2002: 30: 406. doi: $10.1177 / 147323000203000407$.

[13] A. R. White, C. Kaye, J. Poupard, R. Pypstra, G. Woodnutt, B. Wynne, "Augmentin ${ }^{\circledR}$ (amoxicillin/clavulanate) in the treatment of community-acquired respiratory tract infection: a review of the continuing development of an innovative antimicrobial agent" Journal of Antimicrobial Chemotherapy. 2004: 53: Suppl. S1, i3-i20 doi: 10.1093/jac/dkh050.
[14] A. W. Bauer, W. M. Kirby, J. C. Sherris, M. Turck, "Antibiotic susceptibility testing by a standardized single disk method" Am J Clin Pathol. 1966: 45(4): 493-496.

[15] W. L. Drew, A. L. Barry, R. O'Toole, J. C. Sherris, "Reliability of the Kirby-Bauer Disc diffusion method for detecting Methicillin-Resistant strains of Staphylococcus aureus” Applied Microbiology. 1972: 24(2): 240-247.

[16] M. S. Refat, A. M. El-Didamony, I. Grabchev, "UV-vis, IR spectra and thermal studies of charge transfer complex formed between poly(amidoamine) dendrimers and iodine" Spectrochimica Acta Part A. 2007: 67: 58-65. doi:10.1016/j.saa.2006.06.035.

[17] F. Dogan, M. Ulusoy, O. F. Ozturk, I. Kaya, B. Salih, "Synthesis, characterization and thermal study of some tetradentate Schiff base transition metal complexes" J Therm Anal Calorim. 2009: 98: 785-792. doi 10.1007/s10973-009-0205-2.

[18] R. Ebrahimi-Kahrizsangi1, M. H. Abbasi, "Evaluation of reliability of Coats-Redfern method for kinetic analysis of non-isothermal TGA" Transactions of nonferrous Metals (Soc. of china). 2008: 18: 217-221.

[19] V. A. Shelke, S. M. Jadhav, S. G. Shankarwar, A. S. munde, T. K. Chondhekar, "synthesis, characterization, antibacterial and antifungal Studies of some transition and rare earth metal complexes of N-benzylidene-2hydroxybenzohydrazide" Bull. Chem. Soc. Ethiop. 2011: 25(3): 381-391.

[20] H. L. Singh, J. Singh, A. Mukherjee, "Synthesis, Spectral and in-vitro Antibacterial studies of Organosilicon(IV) Complexes with Schiff bases derived from amino acids" Bioinorganic Chemistry and Applications. 2013. doi: $10.1155 / 2013 / 425832$.

[21] N. Raman, J. Joseph, A. Sakthivel, R. Jeyamurugan, "Synthesis, Structural Characterization and Antimicrobial Studies Of Novel Schiff Base Copper (II) Complexes, J. Chil. Chem. Soc., 2009: 54(4): 354-357. Http://Dx.Doi.Org/10.4067/S0717-97072009000400006.

[22] R. C. Maurya, J. Chourasia, P. Sharma, "Synthesis, Characterization and 3D molecular modeling of some ternary complexes of $\mathrm{Cu}(\mathrm{II}), \mathrm{Ni}(\mathrm{II}), \mathrm{Co}(\mathrm{II}), \mathrm{Zn}$ (II), $\mathrm{Sn}(\mathrm{III})$, $\mathrm{Th}(\mathrm{IV})$ and $\mathrm{UO}_{2}$ (VI) with Schiff base derived from the sulfa drugs sulfabenzamide and 1, 10-phenanthroline" Indian Journal of Chemistry. 2007: 46A: 1594-1604.

[23] A. M. Khedr, H. M. Marwani, "Synthesis, Spectral, Thermal Analyses and Molecular Modeling of Bioactive $\mathrm{Cu}(\mathrm{II})$ complexes with 1,3,4-thiadiazole Schiff Base Derivatives. Their Catalytic Effect on the Cathodic Reduction of Oxygen" Int. J. Electrochem. Sci. 2012: 7: 10074 - 10093. 